\title{
DESIGN OF FOOTSTEP POWER GENERATION SYSTEM USING RACK AND PINION GEARS MECHANISM
}

\author{
Muhammad Asad Saeed \\ Trainee Mechanical Engineer \\ Hafiz Foundry Company PVT. LTD.
}

\author{
Nouman Zaffar \\ Mechanical Engineer \\ Honda Breeze, Multan
}

\author{
Muhammad Hamza Tahir \\ Research Associate \\ Department of Mechanical Engineering \\ Pakistan Institute of Engineering and \\ Technology, Multan, Pakistan \\ Arslan Malik \\ Assistant Manufacture Engineer \\ Hafiz Foundry Company PVT. LTD.
}

\begin{abstract}
Energy is the main concern of present day. The production of electric current in a huge amount is the need of today world. There are different methods used for the production of energy like conventional and non-conventional methods. Here I will represent the nonconventional method for the production of electric current. This non-conventional method is "Footstep power generation Mechanism" here the energy will be produce by moving the human on a moving plates in which rack and pinion gear are used to convert the physical energy into mechanical energy and further they will have converted into electric energy by using the dynamo. By using this method, we will have produced the energy to light up the bulb. I will also represent the simulation of the footstep power generator using the ansys17.0 software. By the results its seen we will produce the $10.925 \mathrm{kw}$ power in one hour. This project will be cost effective and easy to installed in a populated area like railway station, bus stands and in shopping malls. Our project is cost effective and easy to implement.
\end{abstract}

Keywords

Foot Step, Electricity Generation, Rack and Pinion gear, Dynamo, Battery, Inverter.

\section{INTRODUCTION}

Now a day's electricity is an important one for human population. The demand of electricity is increasing every day. Man has used remarkable amount of energy for his daily needs. Therefore, large amount of energy has been exhausted and wasted. Whether we realize it or not, energy is an important part of most aspects of daily life. The quantity of life and even its sustenance, depends on the availability of energy. Therefore, it is important to have a good understanding of the sources of energy, the conversion of energy from one form to another and the ramifications of these conversion. The expanded mindfulness that the world's energy assets are restricted has cause numerous nations to rethink their vitality strategies and take extraordinary measures in killing waste. It has likewise started interest for established researchers to investigate the energy change gadgets and to grow new strategies to more readily use the current restricted assets.[1],[2],[3]Therefore, here we will explain a new technique for electricity generation. This new technique work on the law of conservation of energy "energy neither created or nor destroyed its can changed its form". Foot step power generation system is designed to be very useful at public places like railway station, bus stand, shopping malls where lot of people keep walking through all day.[4],[5] This entire human vitality being squandered if can be made workable for usage it will incredible development and group vitality ranches will be extremely helpful vitality sources in packed nations. 


\section{International Journal of Engineering Applied Sciences and Technology, 2019 \\ Vol. 4, Issue 2, ISSN No. 2455-2143, Pages 48-52 \\ Published Online June 2019 in IJEAST (http://www.ijeast.com)}

In this paper portrayed about age electrical power as non-traditional strategy by essentially strolling or running on the stride. On-conventional system is very essential at this time to our nation. Non-ordinary vitality utilizing stride is changing over mechanical vitality into the electrical vitality. There is some method to generate electrical energy from footsteps. Such as gear wheel and flywheel are methods to generate electrical power.[6],[7] This method works on the movement of gear rack or pinion and its mechanical parts are used because this is placed where there are so many people and the energy is produced by their movement on the floor.[8],[9] There is also some other mechanism to produce energy from foot step power generation. Generation of power is done by footsteps from the crowed on floor and piezo plate scheme is used below the floor, then there will be sheet which cover the piezo plate and also spring will be there for vibrating force on piezo sensor.[10],[11] The piezo plate will be struck in the floor such a plate will generate power in the form of electric current. The power which is produced can be used as additional features like street light or light which is used at the place of pedestrians, so the pedestrians should give credit the energy which is produced by their movement.[12],[13],[14] Here we will show the block diagram for foot step power generation system. In this block diagram whole mechanism will be explain step by step working process for the foot step power generation.

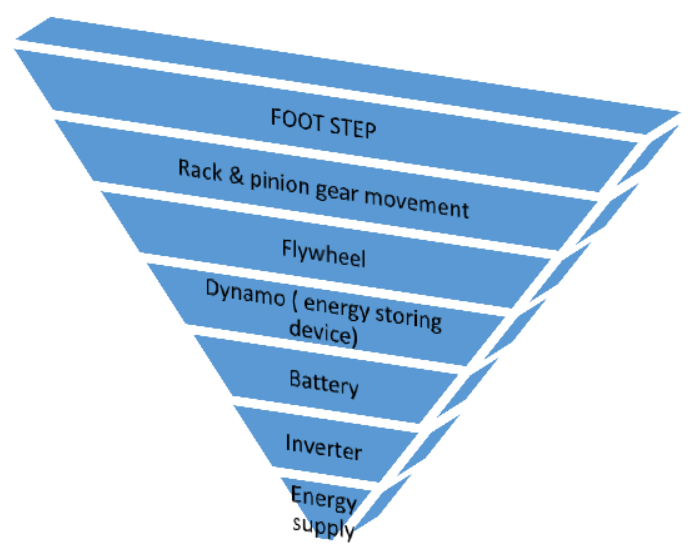

\section{COMPONENT SELECTION} AND DESIGN CALCULATION

\section{a. Frame}

Frame is the foremost supportive element in the system. The frame needs to endure all the heaviness of the exploratory setup. The power applied on the framework is conveyed to the four legs.

\section{b. $\quad$ Rod}

A high carbon alloy steel that is EN8/ AISI 1045 was selected as material for rod. The measurement of rod is given below:

Table2.1 properties of rod

\begin{tabular}{|l|l|l|}
\hline Sr. \# & Properties & Diameter \\
\hline 1. & Height $(\mathrm{H})$ & $120 \mathrm{~mm}$ \\
\hline 2. & Outer diameter $(\mathrm{Do})$ & $22 \mathrm{~mm}$ \\
\hline
\end{tabular}

\section{c. spring}

A spring is characterized as a versatile body, whose capacity is to twist when stacked and to recuperate its unique shape when burden is expelled. There are many types of springs but here we used a helical compression spring and there are four springs used as our requirement. The specification of spring is given below;

Table2.2 properties of spring

\begin{tabular}{|r|l|l|}
\hline Sr. \# & Properties & Value \\
\hline 1. & Height $(\mathrm{H})$ & $100 \mathrm{~mm}$ \\
\hline 2. & Outer diameter (Do) & $30 \mathrm{~mm}$ \\
\hline 3. & Inner diameter (Di) & $24 \mathrm{~mm}$ \\
\hline 4. & Wire diameter (Dw) & $3 \mathrm{~mm}$ \\
\hline 5. & Total no. of turns (ni) & 12 \\
\hline 6. & Active no. of turns(n) & 10 \\
\hline 7. & Spring index $(\mathrm{C})$ & 1.10 \\
\hline 8. & Free length $(\mathrm{L})$ & $92.96 \mathrm{~mm}$ \\
\hline 9. & Pitch of coil $(\mathrm{P})$ & $10.32 \mathrm{~mm}$ \\
\hline
\end{tabular}

\section{d. Rack and pinion}

The gear of a shaft meshes externally and internally with gear in a straight line. Such type of gear is called rack and pinion gear. The straight line gear is called a rack and the circular wheel is called pinion. The specification of rack and pinion gear are given below; 
Table2.3 Specification of pinion

\begin{tabular}{|l|l|}
\hline Material & Cast iron \\
\hline Outside diameter & $75 \mathrm{~mm}$ \\
\hline Circular pitch & $4.7 \mathrm{~mm}$ \\
\hline Tooth depth & $3.375 \mathrm{~mm}$ \\
\hline Module & $1.5 \mathrm{~mm}$ \\
\hline Pressure angle & 21 \\
\hline Pitch circle diameter & $72 \mathrm{~mm}$ \\
\hline Circular tooth thickness & $2.355 \mathrm{~mm}$ \\
\hline Fillet radius & $0.45 \mathrm{~mm}$ \\
\hline Clearance & $0.375 \mathrm{~mm}$ \\
\hline
\end{tabular}

Table2.4 Specification of rack

\begin{tabular}{|l|l|}
\hline Material & Cast iron \\
\hline Module & $1.5 \mathrm{~mm}$ \\
\hline Cross section & $75 \times 25 \mathrm{~mm}$ \\
\hline
\end{tabular}

\section{e. Flywheel}

A flywheel utilized in machines fills in as a repository which stores vitality amid the period when the supply of vitality is more than the necessity and discharges it amid the period when the prerequisite of vitality is more than supply.

Table2.5Specification of flywheel

\begin{tabular}{|l|l|}
\hline Weight & $1 \mathrm{KG}$ \\
\hline Circular dia. & $250 \mathrm{~mm}$ \\
\hline Width & 500 \\
\hline
\end{tabular}

\section{f. Bearing}

A bearing is a machine component which bolster another moving machine component (known as diary). It allows a relative movement between the contact surfaces of the individuals, while conveying the heap. A little thought will demonstrate that because of the relative movement between the contact surfaces, a specific measure of intensity is squandered in conquering frictional obstruction and if the scouring surfaces are in direct contact, there will be quick wear. So as to lessen frictional obstruction and wear and now and again to divert the warmth produced, a layer of liquid (known as ointment) might be given. The oil used to isolate the diary and bearing is generally a mineral oil refined from oil, however vegetable oils, silicon oils, oils and so forth., might be utilized.

\section{g. Dynamo}

Dynamo converts mechanical rotation into electric power. It's a device that makes direct current into electric power using electromagnetism. Its work on a Faradays law. The dynamo uses turning curl of wire and attractive fields to change over mechanical revolution into beating direct current.

\section{h. Inverter}

It's an electric device that convert the direct current (DC) into alternating current (AC). The design of specific circuity depends by the input voltage, output voltage, frequency and overall power handling capacity. The inverter does not provide power but the power is provided with the help of DC source.

\section{i. Battery}

An electric battery is a device consisting of one or more electromechanical cells that convert stored chemical energy into electrical energy. Every cell contains a positive terminal or cathode and a negative terminal or anode. Electrolytes allow ions to move between the electrode and terminal, which allows current to flow out of the battery to perform work.

Specification of battery:

$$
\begin{array}{ll}
\circ & \text { Battery capacity } 121.3 \mathrm{Ah} . \\
\circ & \text { This is chargeable one. } \\
\circ & \text { Battery charging time } 20 \mathrm{~min} . \\
\circ & \text { Working conditions } 2 \mathrm{hrs} .
\end{array}
$$

\section{DESIGN}

This is the 3D assembly of a foot step power generation which is made using a solid works software. We used different commands like rectangle, line, circle and many more commands to design foot step power generation system.

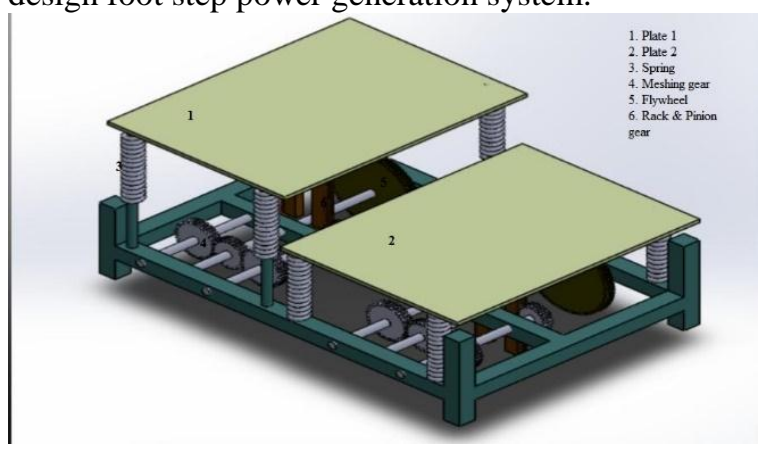

\section{CALCULATION}

Consider 120 man of mass $80 \mathrm{~kg}$ passes over a foot step power generation system in an hour. The height of rack is $14 \mathrm{~cm}$, the diameter of the final pulley is $18 \mathrm{~mm}$ and having revolution speed $(\mathrm{N})$ is equal to 37 


\section{International Journal of Engineering Applied Sciences and Technology, 2019 Vol. 4, Issue 2, ISSN No. 2455-2143, Pages 48-52 \\ Published Online June 2019 in IJEAST (http://www.ijeast.com)}

RPM. Down word motion of foot step is due to the weight of moving the person and upward motion of foot step is take place due to the utilization of energy from springs.

Let's us consider,

Weight(mass) of a man $=\mathrm{m}=80 \mathrm{~kg}$

Force $=\mathrm{F}=\mathrm{mg}=80 \times 9.8=784 \mathrm{~N}$

$\mathrm{r}=9 \mathrm{~mm}$

$\mathrm{T}=\mathrm{r} \times \mathrm{F}(\mathrm{Nm})$

$\mathrm{T}=9 \times 10^{-3} \times 784$

$\mathrm{T}=7.056 \mathrm{Nm}$

$\mathrm{P}=\mathrm{T} \times \mathrm{W}$

$\mathrm{P}=7.056 \times 2 \pi \mathrm{N} / 60$

$\mathrm{P}=7.056 \times 2 \pi 37 / 60$

$\mathrm{P}=7.056 \times 3.87$

$\mathrm{P}=27.34$

Total generated power in forward and reversed stoke.

$\mathrm{P}=2 \times 27.34 \mathrm{~W}$

$\mathrm{P}=54.68 \mathrm{~W}$

Revolution in one minute $=200 / 60=3.33 \mathrm{rev} / \mathrm{min}$

Power generated in one

minute $=54.68 \times 3.33=182.1$ (minute)

Power generated in one

hour $=182.1 \times 60=10925.01 \mathrm{~W}(\mathrm{hr})$

Power generated in one hour=10.925 KW (hr)

\section{WORKING PROCESS}

I. When a person moves from a foot step power generation system the plates move downward direction due to force is applied on the plate by virtue of impressing on the plate the force spring gets compressed.

II. The rack here moves vertically downward.

III. When the rack moves pinion will have engaged with the rack gear results in circular motion of the pinion gear.

IV. For one full compression the pinion moves 1 half circle.

V. When the force will have removed on the plate the pinion reverses and moves another half circle.

VI. The dynamo attached to the pinion hence result in the sinusoidal wave form (for single dynamo).

VII. Then, in this result energy produced will stored on battery for used.

\section{CONCLUSION}

Our work show that in foot step power generation there is no need of fuel to generate the electrical energy. This is also an eco-friendly method for energy production, there is no huge land required to install the as like other energy plants. There is no pollution, no sound, no smoke so this is a best method to install this in public place area. There is no maintenance cost and installation cost is also less as compared to other. We will also make the energy production greater than $10.925 \mathrm{KW}$ (hr) by increasing the size of power generation system. We can further design it for a different size as requirement of energy to full fill. It's also install on parks to light up the lights. Executing this system, we can easily reduce the dependence on the other conventional sources of energy, thus can be considered valuable from that point of view.

In energy crises facing countries where the load shading of electricity are due to the shortage of energy, this foot step power generation system is best method to produce energy and the output of electricity production is increased by increasing the size of foot step power generation system. As compare to other energy producing system the cost of this system is less.

\section{REFERENCE}

[1] Bhosale, P. P. A. et al. (2017) 'Design of Foot Step Power Energy Generation Machine’, 4(June), pp. $943-948$.

[2] Dhanalakshmi, G. et al. (2017) 'Footstep Power Generation System', International Journal of Engineering And Computer Science. doi: 10.18535/ijecs/v6i4.38.

[3] Gothane, A. V and Gosavi, A. R. (2018) 'Foot step power generation', pp. 1582-1584.

[4] Janugade, S. V, Yadav, G. A. and Mahadik, O. R. (2017) 'Foot Steps Power Generation using Mechanical System', 4(1), pp. 55-59. doi: 10.17148/IARJSET/NCDMETE.2017.15.

[5] Journal, D. et al. (2017) 'Footstep Power Generation', 2(7), pp. 8-13.

[6] Journal, I., Technology, E. R. and Volume, S. (2016) 'Power Generation By Foot Steps Using Rack', International Journal of Engineering 
Research And Advanced Technology (IJERAT), 2(01), pp. 10-14.

[7] Marshiana, D. et al. (2016) 'Footstep power production using piezoelectric sensors', Research Journal of Pharmacy and Technology, 9(7), pp. 831834. doi: 10.5958/0974-360X.2016.00157.8.

[8] Munaswamy, B. et al. (2018) 'Mechanical Footstep Power Generation', 5(2), pp. 291-298.

[9] Pokale, R. S. (2016) 'Design and analysis of a Mechanical Device to harvest energy from human footstep motion', 3(1), pp. 1-5.

[10] Prabhavathi, K. (2017) 'Foot Step Power Generation Using Piezoelectric Material 2016-2017', 1(1), pp. 595-600.

[11] Saif, A. (2016) 'Generation of Electrical Energy from Foot Step Using Rack and Pinion Mechanism', 3(4), pp. 693-699.

[12] Sarnaik, J. R. (2018) 'Implementation of Mechanical Power on Footstep Power Generation System', pp. 205-209.

[13] Suresh, S. et al. (2018) 'Design and Fabrication of foot step power generation using rack and pinion assembly', 4(8), pp. 24-26.

[14] Vasantharaj, A., Haridevi, P. and Dhivya, M. (2016) 'ELECTRICAL POWER GENERATION USING FOOT STEPS', 2(10), pp. 1412-1424. 